\title{
Socio-cognitive Presence and Transactional Distance in a Learning Community for Graduate Student Research Training
}

\author{
Gustavo Adolfo Angulo Mendoza, Université TÉLUQ, Canada \\ gangulo@teluq.ca
}

\begin{abstract}
This research aims to determine how an increased socio-cognitive presence (Jézégou 2012) modulates transactional distance (Moore 1993) in a graduate research learning context. In other words, the main goal is to determine if, and in what way, the social interactions taking place in a technology-mediated community can lessen the difficulties associated with transactional distance, and how these interactions would support learning the scientific research process. This research is based on a case study conducted in a community of research and mutual assistance at a Canadian university. This community aims to develop graduate students' scientific skills, support their research work, and gradually integrate them into the professional community. In total, 15 students and four faculty members were interviewed. A mixed content analysis method was used, including quantification of code co-occurrences and an interpretative analysis of participants' comments. The study shows that, in a graduate research training context, increasing socio-cognitive presence through interactions within a technology-mediated community promotes students' perceptions regarding the availability of peers and faculty. This, in turn, reinforces the sense of connection between students, and between students and faculty.
\end{abstract}

Keywords: Research Training, Graduate Students, Learning Community, Socio-cognitive Presence, Transactional Distance

\section{Introduction}

In recent decades, graduate education has seen a significant increase in the number of part-time students enrolled, in part due to the growth of distance education and open universities (Evans 2002). This increase in student enrolment has led to challenges for faculty members in directing student research (Mitchell and Carroll 2008) and in paying attention to their needs for education about the scientific research process, socialization, scientific enculturation, guidance in conducting research projects, and personal, emotional or psychological support (Lee 2011).

Learning about scientific research at the graduate level is a complex and multidimensional process that poses major challenges for supervisors and students. Transactional distance could be a catalyst for research learning difficulties (Silinda and Brubacher 2016). One of the endemic challenges of graduate research training is the establishment and maintenance of fruitful relationships between faculty and students (Mainhard et al. 2009). Graduate research training involves introducing the student, as a new member of the scholar community, to its practices (Lee 2008).

In graduate studies, difficulties related to transactional distance can be a major obstacle, even for the most motivated students. Because of its very particular and specialized orientation, graduate research relies on reading, thinking and writing on a rather solitary basis (Mills 2002). There is evidence that the feeling of isolation of students and their supervisors may be greater at a distance (Willems et al. 2011), although it can be quite intense for any Master's or Ph.D. student (Ismail, Abiddin, and Hassan 2011). Success 
in graduate studies depends as much on sustained, systematic, and solitary effort as it does on intellectual abilities.

The challenge is to explore the relational needs of the student in order to offer appropriate networking and support strategies. In the opinion of Evans, Hickey, and Davis (2004), strategies that work well with undergraduate students (e.g., student groups structured around athletic, cultural and religious activities) may not be as successful for some graduate students. In order to reduce difficulties in learning about scientific research, several solutions have been explored: research supervision training for faculty, research methods training for students, and changes to supervision approaches aimed at increasing the feeling of presence (e.g., Nordentoft, Thomsen, and Wichmann-Hansen 2013). Models of research supervision based on a group approach are increasingly being explored at the doctoral level (Boud and Lee 2005; Crossouard 2008; Flores-Scott and Nerad 2012; Ford, Branch, and Moore 2008; Green 2006; Olson and Clark 2009; Paliktzoglou, Rogers, and Suhonen 2010; Parker 2009; Wagener, Boujon, and Fromage 2010; Wegener, Meier, and Ingerslev 2014; Wisker 2007), where the literature reveals a growing trend towards promoting a collaborative approach to research learning. At the Master's level, however, studies remain scarce (Choy, Delahaye, and Saggers 2014; Johnston 1995; Wichmann-Hansen, Thomsen, and Nordentoft 2014).

Course completion is generally not an issue for most students in research-based programs, (Lovitts 2005). They face a greater challenge: undertaking research work whose main outcomes will be evaluated by members of the scientific community. Munich (2014) argues that graduate students appreciate activities that support their research project, but do not welcome activities that appear to be incidental to their goals. Some students are frequent users of social networks and online communities, while others might only be neophytes.

Studies of graduate students (Ford, Branch, and Moore 2008; Green 2006; Lee et al. 2006; Paliktzoglou, Rogers, and Suhonen 2010) suggest that they are generally very receptive to community activities involving authentic and successful tasks, and are generally reluctant to participate in activities that are strictly community-building. The development of learning communities in graduate programs should recognize the tension between a community-based exercise and the individualistic imperative to develop knowledge and expertise in research in the field (Samara 2006).

Graduate research training is a complex process with many dimensions. Students often face multiple challenges in conducting research projects and writing dissertations. These difficulties occur on several levels: affective/emotional, cognitive and communicational. While peer support could help to overcome these difficulties (Maltais and Deschenes 2013; Papi 2013), students experiencing challenges often work alone.

The aim of this research is to determine the extent to which increasing socio-cognitive presence through a technologically mediated learning community modulates transactional distance in a graduate research learning context.

\section{Framework}

Socio-cognitive presence refers to interactions between learners who seek to solve a problem situation collaboratively. Transactional distance refers to a gap between participants in a learning situation. The goal of this research is to better understand how increasing the level of interaction reduces the magnitude of this gap in a graduate research training context. 


\section{Socio-cognitive presence (SCP)}

SCP results from transactions between students when they come together to solve a problem situation by collaborating using synchronous or asynchronous communication tools. SCP contributes to developing a learning community (Jézégou 2012, 2013, 2014, 2019).

SCP is central to critical thinking, which is considered both a process and a major outcome of graduate education. A collaborative approach to solving a problem situation requires transactions, i.e., interactions between members of the group (Dewey and Bentley 1949). These interactions involve the expression and confrontation of differing points of view, deliberation and negotiation, and mutual adjustment.

\section{Transactional distance in research training}

Transactional distance (Moore 1993) is a cognitive, psychological and communicational gap between faculty and students that needs to be bridged. Its measurement is a function that involves two interdependent variables: dialogue, i.e., the level of interaction between students and faculty; and structure, i.e., the degree of flexibility (or rigidity) of the educational relationship. These two variables determine the level of autonomy required of students.

Transactional distance (TD) is a perception of low availability of the other actors in an educational situation, and a feeling of disconnection (Shin 2002). Several factors determine TD between the supervisor and the student: experience gaps, non-aligned research interests (Belleville 2014), a lack of interaction (Cotterall 2011; Habib and Morrow 2007; Wright 2016; Grossman and Crowther 2015), an overestimated level of student autonomy (Belleville 2014), a "laissez-faire" supervision style defined by a low level of structure and support, or a "pastoral" style marked by frequent interactions, but which do not necessarily lead to effective transactions (Gatfield 2005).

A sense of peer disconnection is reinforced by the view that the specialized nature of student projects results in a solitary journey (Mills 2002). Students must deal with isolation that is often considered intrinsic to graduate studies (van der Meer, Spowart, and Hart 2013). Many students struggle to connect with peers for support in addition to the support provided by their supervisor (Conrad 2003).

\section{Structure in graduate research training}

Structure in graduate research training consists of elements that provide a general orientation for students in their learning and in carrying out their work. According to Gatfield (2005), the structural factor elements of graduate student supervision can be classified into three categories: organizational process, accountability and stages, and skills provision (Table 1).

Table 1: Structural Factor Elements of Graduate Student Supervision

\begin{tabular}{|l|l|l|}
\hline \multicolumn{1}{|c|}{ Organizational process } & \multicolumn{1}{|c|}{ Accountability and stages } & \multicolumn{1}{c|}{ Skills provision } \\
\hline Selecting candidates & Contractual arrangements & Methodologies \\
Identifying roles & Negotiated meetings evaluation & Writing \\
Negotiating meetings & Milestone evaluations & Statistics training \\
Setting the topic & Establishing time frames & Computer software \\
Setting stages and goals & Staged write-up & Oral presentations \\
Scheduling group meetings & Supervisor turn-around time & Time management \\
Recording meetings & Supervisor stage feedback & Short training seminars \\
Progress reports & Report evaluation & \\
\hline
\end{tabular}




\begin{tabular}{|l|l|l|}
\hline \multicolumn{1}{|c|}{ Organizational process } & \multicolumn{1}{|c|}{ Accountability and stages } & \multicolumn{1}{c|}{ Skills provision } \\
\hline Supervisor availability & Oral defence & \\
Consistent contact & Colloquiums evaluation & \\
Supervisor input & Conference evaluation & \\
Changing supervisor role & Publications & \\
Maintaining focus & & \\
Colloquiums and conferences & & \\
External reference & & \\
Group supervision & & \\
Informal structure & & \\
Time flexibility & & \\
Supervisory model & & \\
\hline
\end{tabular}

Source: Gatfield $(2005,315)$

\section{Dialogue in graduate research training}

Dialogue in graduate research training consists of interactions that students have with supervisors, other faculty, peers, and experts in the field. Certainly, student-supervisor interactions have the most significant impact on students in carrying out their projects. However, interactions with other faculty have an impact of varying intensity on certain aspects of the research project.

For Ewing et al. (2012), the role of peers is fundamental in graduate research training. Peer discussion allows students to analyze research methods and reflect on how they can be applied to research projects. As students become familiar with the methods and techniques of data collection and analysis, they can present their tools, instruments and processes to peers, and receive feedback from them. Ewing et al. (2012) recommend encouraging students to share their feedback, ask thought-provoking questions, and provide resources that contribute to the development of their peers' projects. Ewing et al. (2012) also recommends that the supervisor take an active role in the dynamics of interactions, providing clarification and encouraging constructive dialogue.

For Ewing et al. (2012), a research training program should provide opportunities for students to present their outcomes to peers and faculty after completing each stage of their projects. Synchronous communication technologies support the creation of an environment encouraging discussion, questioning, feedback, and resource sharing. Asynchronous communication technologies also enable exchanges, formative evaluation and questioning (Ewing et al. 2012).

\section{Development of autonomy in graduate research training}

The main objective of graduate studies is to develop the ability to conduct independent research projects. This is achieved through supervised decision-making regarding the student's research project. The gradual empowerment of students regarding the various elements of their projects is essential for cultivating autonomy. Difficulties related to defining the object of study and those related to the design, implementation and management of the research process forge the student's ability to conduct independent research.

Transitioning from student to researcher is a crucial aspect of graduate research training, and exercising autonomy is a key factor in this transition (Lovitts 2005). The relationships that students maintain with their supervisors, peers and networks support the development of autonomy. Self-efficacy can be promoted by encouraging students to think and act independently, while providing the necessary guidance for them to carry 
out their research (Overall, Deane and Peterson 2011). In addition, agentivity can be enhanced through feedback highlighting the concrete contributions that students make in carrying out their work (McAlpine and Amundsen 2015). By becoming involved in participation bodies, students build their identity within their discipline and develop selfconfidence. Similarly, this identity and confidence are built through participation in scientific activities.

Regarding the development of autonomy, graduate research training has several objectives: first, to support students in defining and managing their research process; secondly, to guide them in exploring solutions to the difficulties that they encounter; thirdly, to promote their ability to act and exert influence on their environment; and fourthly, to encourage them to take responsibility for managing their research projects and their research training.

\section{Context: A community for research training}

This study was carried out in the context of a community that has been operating within a Canadian university for 15 years and is comprised of graduate students and education professors who advocate for a community and partnership approach to supervision. This para-institutional community promotes the effective supervision of many students in a rich, formative, cooperative and stimulating environment.

This community aims to support the success of students, develop their scientific skills, and promote their professional integration. It seeks to break isolation and extreme individualism, and to help students overcome the psychological traumas experienced by so many of them: burnout, depression, separation, divorce, etc. In addition, it focuses on developing skills to complement hyperspecialized scientific training.

The activity of this community is organized into cells, which are working groups assigned to specific tasks (Figure 1). There are two types of cells: community cells designed to organize common services between members (coordination, partnership and cooperation, progress in studies, training, and scientific dissemination) and thematic cells organized according to research interests (institutional evaluation, policy analysis, and educational development).

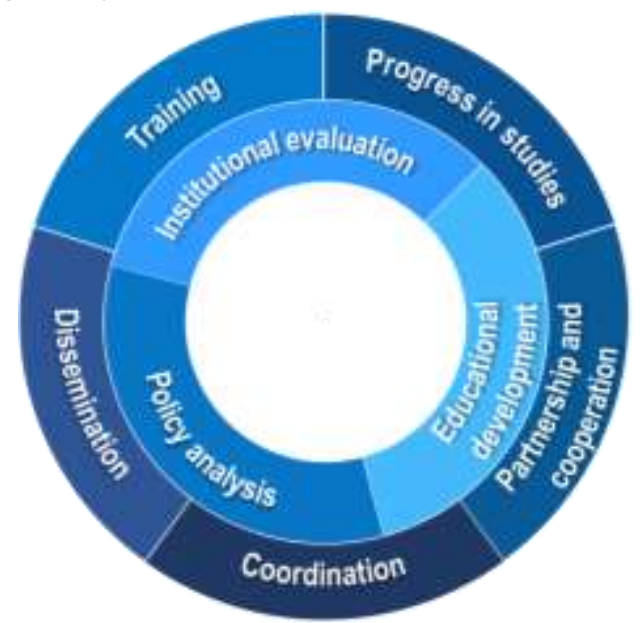

Figure 1: Community Structure Source: Author, 2020 
In order to achieve its objectives, the community proposes activities based on a socioconstructivist approach, characterized by intense interaction dynamics and opportunities for results-oriented collaboration. These activities make up the "research school" (Figure 2).

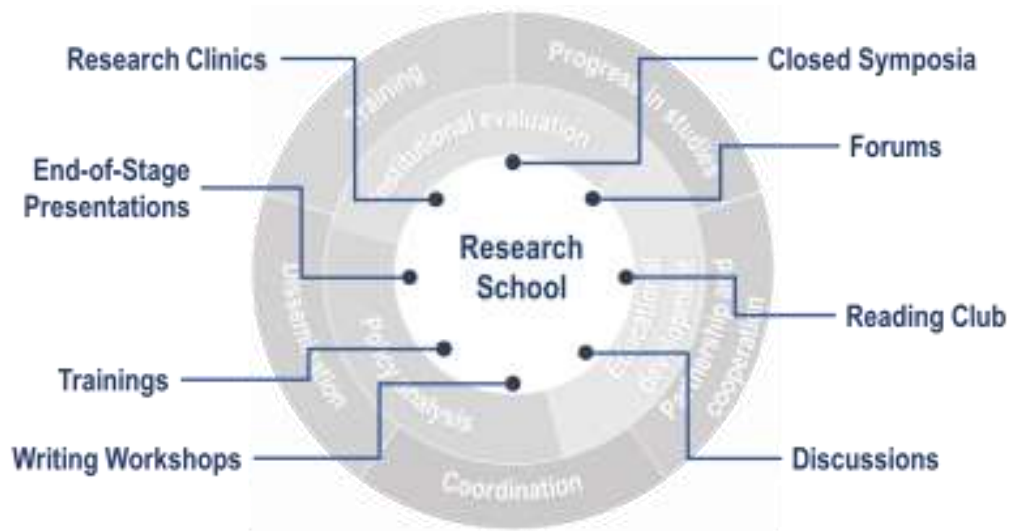

Figure 2: Activities within the Community Source: Author, 2020

At the time of this study, the community had 36 graduate students from two programs. Table 2 shows the distribution of students.

Table 2: Distribution of Students

\begin{tabular}{|l|c|c|}
\hline Degree Program & Education administration and policies & Measurement and evaluation \\
\hline Master's & 9 & 10 \\
\hline Ph.D. & 6 & 11 \\
\hline
\end{tabular}

Seven faculty members are part of the supervisory team, four of whom (P1, P2, P5 and P7) work in the same department. Three faculty members are attached to other universities (P3, P4 and P6). Table 3 shows the characteristics of faculty

Table 3: Characteristics of Faculty

\begin{tabular}{|l|l|l|l|l|}
\hline & \multicolumn{1}{|c|}{ Status } & $\begin{array}{l}\text { Scholar } \\
\text { experience }\end{array}$ & \multicolumn{1}{|c|}{ Qualifications } & Main Research Theme \\
\hline P1 & $\begin{array}{l}\text { Tenured } \\
\text { Professor }\end{array}$ & 16 years & $\begin{array}{l}\text { M.A. and Ph.D. in Measurement and } \\
\text { Evaluation }\end{array}$ & $\begin{array}{l}\text { Institutional evaluation, } \\
\text { program evaluation }\end{array}$ \\
\hline P2 & $\begin{array}{l}\text { Associate } \\
\text { Professor }\end{array}$ & 5 years & $\begin{array}{l}\text { M.A. in Sociology and Ph.D. in Applied } \\
\text { Human Sciences }\end{array}$ & $\begin{array}{l}\text { Social construction of } \\
\text { educational policies }\end{array}$ \\
\hline P3 & $\begin{array}{l}\text { Associate } \\
\text { Professor }\end{array}$ & 15 years & $\begin{array}{l}\text { M.A. in Organizational Management and } \\
\text { Ph.D. in Educational Administration and } \\
\text { Evaluation }\end{array}$ & $\begin{array}{l}\text { Educational planning } \\
\text { and management }\end{array}$ \\
\hline P4 & $\begin{array}{l}\text { Assistant } \\
\text { Professor }\end{array}$ & 4 years & $\begin{array}{l}\text { M.A. in Sociology and Ph.D. in } \\
\text { Educational Administration and } \\
\text { Evaluation }\end{array}$ & $\begin{array}{l}\text { Development of } \\
\text { education in non- } \\
\text { industrialized countries }\end{array}$ \\
\hline P5* & $\begin{array}{l}\text { Tenured } \\
\text { Professor }\end{array}$ & 16 years & $\begin{array}{l}\text { M.A. and Ph.D. in Educational } \\
\text { Administration }\end{array}$ & $\begin{array}{l}\text { Educational planning } \\
\text { and management }\end{array}$ \\
\hline P6* & $\begin{array}{l}\text { Assistant } \\
\text { Professor }\end{array}$ & 2 years & M. A. and Ph.D. in Education & $\begin{array}{l}\text { Measurement and } \\
\text { evaluation }\end{array}$ \\
\hline P7* & $\begin{array}{l}\text { Tenured } \\
\text { Professor }\end{array}$ & 15 years & $\begin{array}{l}\text { M. A. in Education and Ph.D. in } \\
\text { Measurement and Evaluation }\end{array}$ & $\begin{array}{l}\text { Measurement and } \\
\text { evaluation }\end{array}$ \\
\hline
\end{tabular}

${ }^{*}$ P5, P6 and P7 did not participate in the study 
Communications between members take place using a videoconferencing system and a Learning Management System (LMS). Members have access to learning activities both in face-to-face mode and online (synchronously or asynchronously). Figure 3 shows the technological architecture.

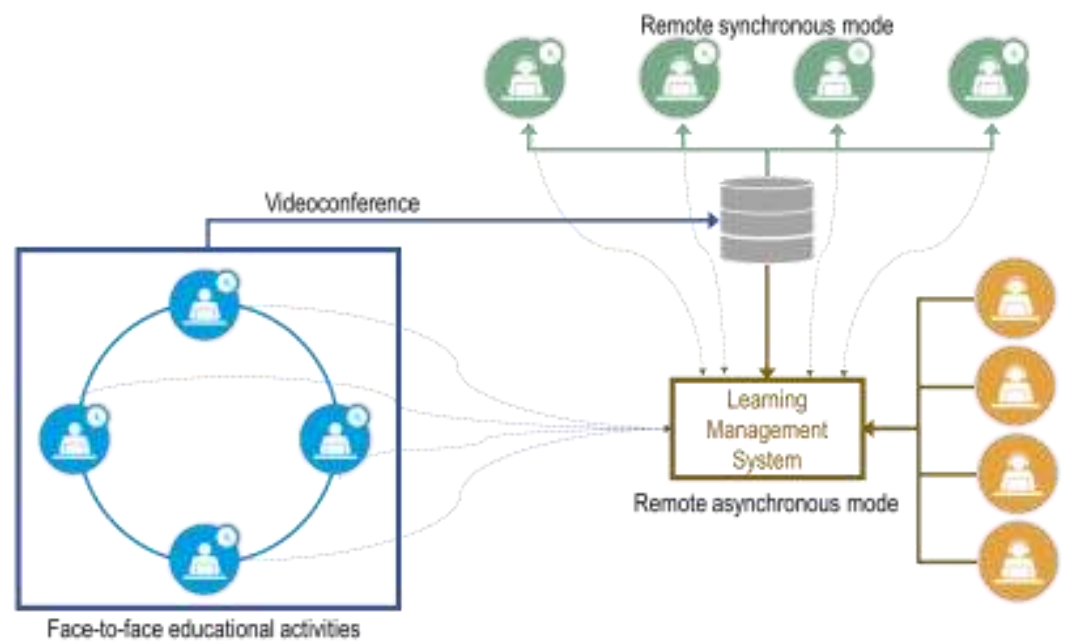

Figure 3: Technological Architecture Supporting the Community Source: Author, 2020

\section{Research Method}

\section{Participants and recruitment}

Fifteen students (10 Master's and five (5) Ph.D. students) and four professors agreed to participate. A sample of voluntary participants was selected for opportunity and convenience (Hernández-Sampieri and Mendoza 2018). We contacted community leaders in the early Fall of 2018 to begin recruitment. Information on the research and a description of the required participation was communicated in early September 2018 during the first community meeting of the 2018-2019 academic year. During the week following this meeting, a copy of the consent form was sent to professors and students by email for potential participants to review. The consent form was signed during subsequent meetings. This allowed us to begin conducting interviews.

\section{Instruments, data collection and analysis procedure}

Interviews were conducted using a semi-structured questionnaire. Data collection took place during the Fall 2018 term. Following the technique of thematic content analysis, the information was processed by codifying the data corpus based on a model consisting of two categories. The first category covers the following topics: structure of supervision (Gatfield 2005), dialogue (Ewing et al. 2012) and development of student autonomy (Godskesen and Kobayashi 2016). The second category is derived from the work of Jézégou (2010, 2012, 2013, 2014, 2019), who defines SCP as transactions between learners when they come together to solve a problem situation by collaborating using synchronous or asynchronous communication tools. This category encompasses the following topics: confrontation of points of view, mutual adjustment, negotiation, deliberation, and sharing of knowledge, difficulties and experiences. 
In order to link the SCP and TD categories, a mixed content analysis method was used. Following Osgood's method as described by Bardin (2013), the associations that appear after the co-occurrences have been calculated and analyzed are representations of the participants' associative structures. The method used postulates a correspondence between textual co-presence and actual association.

The corpus consisted of interview transcripts. The content analysis method proposed by Bardin (2013) is organized around three phases: (1) pre-analysis, (2) processing of the data, and (3) results processing, inference and interpretation. Following the constitution of the corpus, four actions were carried out in the pre-analysis phase: "floating" reading; identification of indices and elaboration of indicators; preparation of the data, and pretest analysis. The processing of the data consisted of coding the 417 context units that resulted from the parsing of the interview transcripts. The coding was based on the following code tree using QDA Miner analysis software:

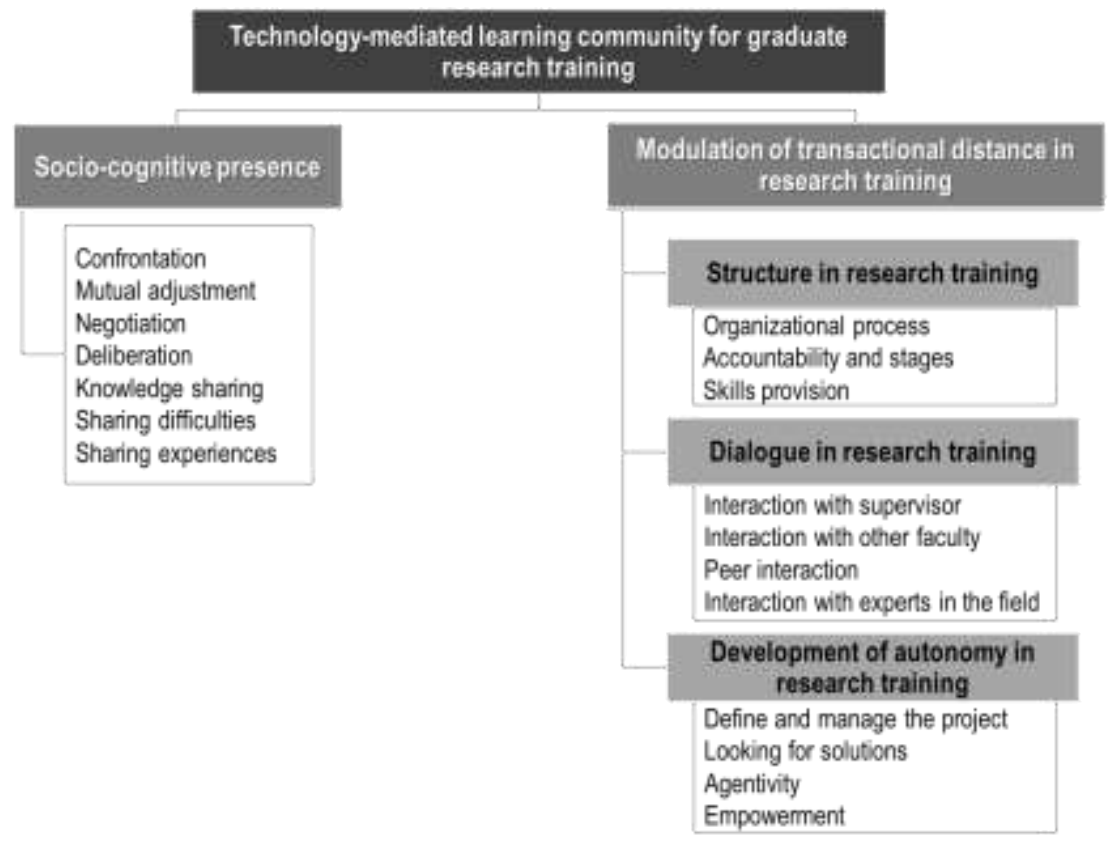

Figure 4: Code Tree

Source: Author, 2020

Using the mixed analysis software, the absolute and relative frequencies of all codes were calculated. An analysis of the relationships by quantifying co-occurrences complements the simple frequency analysis. We used the Jaccard coefficient to measure the degree of similarity between two codes based on the number of cooccurrences between them. We then proposed inferences and advanced qualitative interpretations in line with our research objectives. By comparing what participants said, we were able to arrive at an update of participants' perceptions of the impact of SCP on TD modulation.

\section{Results}

Figure 5 shows the cluster plot based on all components of the study's two dimensions. 


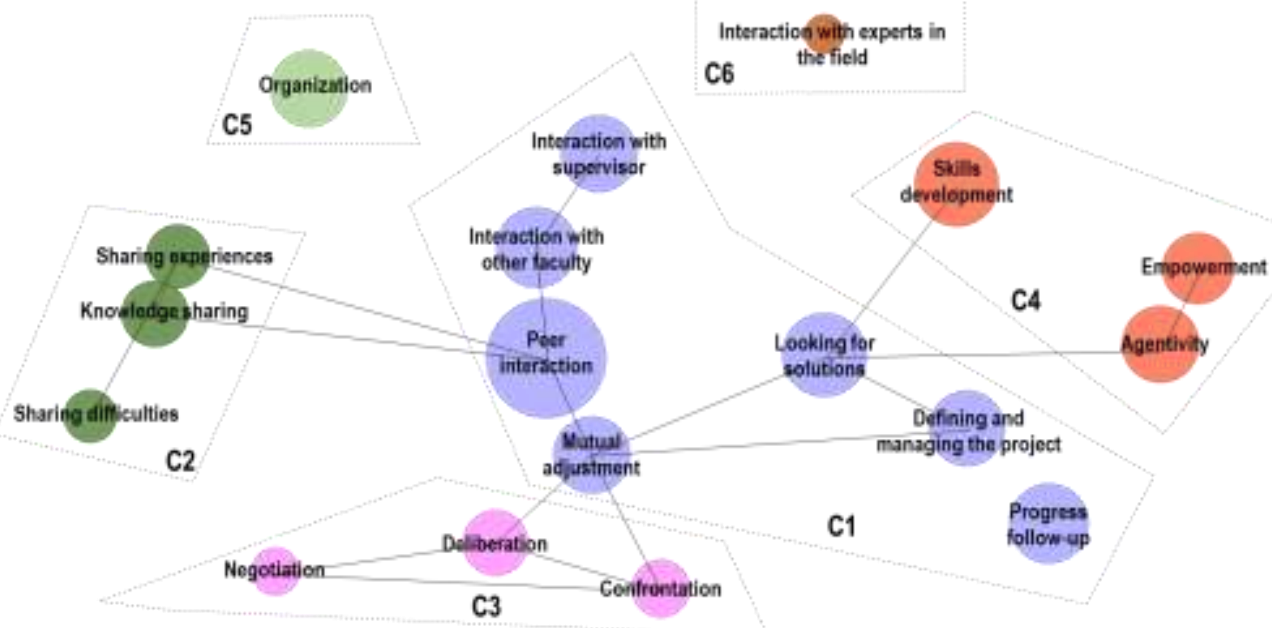

Figure 5: Cluster Plotting from SCP and TD Codes Source: Author, 2020

The number of clusters has been set at six. After several iterations, we found that this number of clusters optimally represents the associations of the elements. The lines in the diagram indicate the strongest links where similarity was highest (Jaccard coefficient, $J \geq 0.300$ ). The length of the radius of each circle represents the frequency of the respective code. Thus, Cluster $\mathrm{C} 1$ brings together interactions between members of the community (student peers, supervisor and other faculty members), mutual adjustment transactions, development of the ability to find solutions to difficulties in carrying out the project, the ability to better define and manage a research project, and follow-up of the student through the stages of his/her project. Linking these codes in the same cluster would indicate that the dynamics of dialogue between community members allow student-researchers to confront their own thinking with that of others, and possibly to reconsider their representations. This favors their empowerment in the sense that new knowledge gained through this adjustment enables them to explore possible solutions to the difficulties encountered in their research, to take responsibility for managing their projects, and to make efficient progress.

Cluster C2 brings together interactions resulting in the sharing of knowledge, experiences and difficulties. The "peer interaction" code has strong links with the codes for "sharing of experiences" $(J=0.311)$ and "knowledge sharing" $(J=0.327)$. This reveals that, for participants, the value of peer interaction lies in the opportunity to benefit from each other's experiences and learning in carrying out their projects. Sharing, which is one of the founding values of this community, constitutes a cluster in its own right in the participants' discourse.

Cluster $\mathrm{C} 3$ brings together negotiation, deliberation and confrontation transactions. The latter two have strong links with mutual adjustment transactions $(J=0.348$ and 0.381 respectively). This can be explained by the fact that representations are reconsidered, and ways of thinking are confronted as a result of examining the different aspects of an issue, carried out by all members, in a collegial manner.

Cluster C4 groups together the codes for "skills development", "empowerment" and "agentivity". Associating these codes in the same cluster would indicate that developing research know-how increases confidence in the students' abilities, which in turn 
promotes the ability to produce an effect on the conditions that student-researchers face in their research projects, but also the ability to produce an effect on their peers, to influence them and to transform the community.

Interestingly, two codes ("organization" and "interaction with external experts") form clusters in their own right, but for different reasons. Cluster C5 is only composed of the "organization" code. This code appears 115 times in the entire corpus $(1.7 \%$ of the coding), in 100 context units, representing $24.0 \%$ of the units. The organization of the learning system and its relationship with the frequency and intensity of transactions were topics to which participants attached importance, as we will see in the interpretative analysis of the discourse. Cluster C6 consists only of the "interaction with external experts" code. The latter is found 32 times $(0.5 \%)$ in 27 context units $(6.5 \%)$. The low presence of this code in participants' discourse made it difficult to establish similarity links with other codes.

\section{Socio-cognitive presence and setting up the structure}

Throughout the corpus, the co-occurrences of codes belonging to the "SCP" and "structure" categories make it possible to identify more subtle links in this reciprocal relationship (Table 4).

Table 4: Co-occurrences of Codes of the "SCP" and "Structure" Categories

\begin{tabular}{|l|l|l|l|}
\hline $\begin{array}{l}\text { Structure } \\
\text { SCP }\end{array}$ & Organization & Progress follow-up & Skills development \\
\hline Confrontation & 11 & 22 & 17 \\
\hline Mutual adjustment & 16 & 28 & 35 \\
\hline Negotiation & 5 & 10 & 9 \\
\hline Deliberation & 15 & 25 & 23 \\
\hline Knowledge sharing & 11 & 13 & 30 \\
\hline Sharing difficulties & 8 & 18 & 9 \\
\hline Sharing experiences & 15 & 16 & 30 \\
\hline
\end{tabular}

Regarding the relationship between the creation of SCP and the formal organization of this training system, the participants' discourse makes it possible to identify reciprocity between two elements: on the one hand, the intensity and frequency of transactions; and, on the other hand, the implementation of structural elements that affect organization, monitoring of progress, and skills development.

Table 4 shows a relatively high number of co-occurrences of the "skills development" code, in the "structure" category, with the codes for "mutual adjustment" (35), "knowledge sharing" (30), "sharing experiences" (30) and "deliberation" (23)under the "SCP" category. This would be indicative of how students perceive the impact of transactions on the development of their skills as scientific researchers. Similarly, the code "progress follow-up" is frequently found with the codes for "mutual adjustment" (28), "deliberation" (25) and "confrontation" (22). The simultaneous presence of these codes in the participants' discourse indicates that this type of interaction enables students to evaluate the progress of their own study project by comparing it with the projects of their peers. The co-occurrences of the "organization" code ("structure" category) and the various codes under the "SCP" category suggest that, for community 
members, cognitive exchanges participate in shaping the community and, in turn, the structure of the community affects the frequency and intensity of these transactions.

The shared experiences of all members contribute to the organization of the group and individual supervision system. Thus, the pooling of the particularities of each student research project "shapes", to a certain extent, the supervisory model, which is nurtured by this sharing. The strength of the interactions within the group is then a function of the quantity, but above all the quality of the knowledge and experience that they convey. In return, the organization of the supervision system, based mainly on this SCP, encourages transactions and sharing. One of the participants described the relationship between SCP in the community and the structuring of the research training process as follows:

[...] the experience of others becomes contributory in the coaching of everyone and it's not just the experience of the supervisor that contributes, it's the experience... if there are ten, well, there are ten brains that contributed to the structuring of this session, so it's richer. You see, what's interesting in a research process, depending on the angles and the subjects, the people, there's a variation, I mean a methodological variation, a variation of instruments, a variation of methods, and the fact that the student was leaning... moreover it is current! It's not references that are 15 or 20 years old, no. He's digging into something with current references. So it's another added value that a professor sometimes doesn't have the time to dig that much into these specifics. Sometimes you will find in a methodology or a method 30 ways to collect your data, or 30 perspectives to process them, and when people individually look at it, well, you have this richness that is brought back to the group, that's another plus. (E2)

Many participants emphasized this relationship between the richness of the transactions and the establishment of a structure for developing research skills. Group members gain information about each other, about the ways in which they conduct their research processes, and about each other's approaches to carrying out their student projects. Group awareness is enhanced by activities that promote the exchange of knowledge, experiences and difficulties, as well as through mutual confrontation and adjustment. A metaphor used by one participant illustrates the way in which the group and the transactions between its members contribute to each student's individual process:

[...] research is like a causal chain. You have to document every step you make and to capture it you have to be in the kitchen, you have to cook the dish to capture a little bit how the ingredients interact with each other, what temperature it takes for them to simmer; you have to be really into the practice and what happens with the community is that it gives us a chance to be in other people's kitchens as well.

There are two ways when we invite people to our house, we can invite them, the dish is already prepared, we put them in the living room or in the place to serve, they take the meal, we chat, then they leave. And there is another way, maybe we like it a little bit more, well, we'll invite them because we want to spend more time, we'll invite them even in our kitchen, then they prepare with us, they simmer the dish, we innovate together, sometimes there are spices that some people put and others don't, but oops! he has an idea, but why don't you put this spice in your dish? It will enhance it; or, wait! You don't put this or that right away, wait! because... and it's a bit of a co-construction. (E7)

It seems to be essential to the structure of this community for its members to have the chance to be "in the kitchen of others", to examine the tools, processes and results of peer processes, or to "cook with others": in other words, to collaborate in the construction of each person's project, while learning through the process. Although peer contributions are subsequently "filtered" by the student and his/her supervisor, the 
feeling of having participated in the production of a high-level learning product fosters commitment to developing the training system: "when someone makes a presentation, they are asked questions. Of course, it's up to the supervisor and the student to make the choice" (E4).

Peer contributions are facilitated by the fact that members belong to the same field of study, which promotes relevant exchanges and sharing. The confrontation of divergent points of view, which also contributes to the creation of SCP, enriches transactions between members. One student put it this way: "I think that things like this have to be born. Even if we are in a community, we must live it concretely too, between individuals, we must be able to create links. That's where we have converging interests... or not. It may not be convergent, but the more convergent it is, the more concepts you have that intersect and the more easily you can..." (E6).

Moreover, students' progress and research projects are also affected by SCP, in the sense that transactions are involved in defining projects. In the same way, the effort to define one student's project encourages other students to share their learning and experiences. Professor P3 demonstrates this relationship between SCP and progress as follows: "Study projects move a lot, it moves and a student... but in the community this kind of movement at the beginning is clearly seen, as a professor we see the evolution in the definition of the object and in its implementation to find its own methodology. All this is difficult, and the community allows learning through the transfer of knowledge both by the professor and between them". However, the creation of SCP is a process that takes time to develop and is characterized by increased complexity compared to an individual path, as student E6 indicates, "[...] it is not easy either to build this kind of team to work effectively because the research is really about the team. Individually you can do it, but it's not easy. Some people just do it. They're very intelligent, but most of them need an outside perspective [...]" (E6).

Willingness to participate in the creation of SCP is a sine qua non condition for organizing such a community. Several participants suggested that learning as a social construction should be favored in order to successfully establish a community for research training. In this regard, Professor P1 states, "I like to work in a social way where everyone's contributions enrich what we do [...]," which is in line with the comments of student E6: "I was very interested because conducting research in silos, in isolation, is not the best way."

\section{Socio-cognitive presence or reinforcement of dialogue}

Creating SCP can be likened to reinforcing dialogue between members of the community, especially between students. This is suggested by the simultaneous presence of the codes of the "SCP" and "dialogue" categories (Table 5).

Table 5: Co-occurrences of Codes of the "SCP" and "Dialogue" Categories

\begin{tabular}{|l|c|c|c|c|}
\hline SCP & $\begin{array}{l}\text { Dialogue } \\
\text { supervisor }\end{array}$ & $\begin{array}{l}\text { Interaction with } \\
\text { other faculty }\end{array}$ & $\begin{array}{l}\text { Peer } \\
\text { interaction }\end{array}$ & $\begin{array}{l}\text { Interaction with } \\
\text { experts in the field }\end{array}$ \\
\hline Confrontation & 23 & 29 & 55 & 1 \\
\hline Mutual adjustment & 38 & 45 & 94 & 2 \\
\hline Negotiation & 11 & 18 & 34 & 0 \\
\hline Deliberation & 25 & 35 & 58 & 5 \\
\hline
\end{tabular}




\begin{tabular}{|l|l|l|l|l|}
\hline Knowledge sharing & 19 & 33 & 65 & 11 \\
\hline Sharing difficulties & 17 & 23 & 44 & 1 \\
\hline Sharing experiences & 25 & 28 & 61 & 8 \\
\hline
\end{tabular}

The highest numbers of co-occurrences occur with the "peer interaction" code. This would indicate that the transactions that students have with their peers exert a strong influence on TD measurement, with respect to dialogue frequency and intensity. In other words, the richness of dialogue is a function of the quantity and quality of peer transactions.

Interestingly, co-occurrences between the different codes in the "SCP" category and the "interaction with other faculty" code are, in all cases, higher than with the "interaction with supervisor" code. This suggests that, for participants, the community is a forum for exchanging ideas, debating, and sharing learning and experiences with all members, rather than a space that reflects the two-way dialogue that each student has with his/her supervisor. In this way, student-researchers can benefit from the comments and advice of all faculty members who are part of the community, in addition to the individual guidance provided by their supervisor on specific aspects.

The "interaction with experts in the field" code does not show a significant number of cooccurrences with the codes in the "SCP" category, which could be explained by the low attendance of external experts at the sessions, at least during the period when our observation took place. However, three roundtable-type activities with people from outside the community were held during the data collection period, which provided participants with the opportunity to interact with experts in the field from outside the community.

Most of the students who were interviewed place a high value on feedback from peers in the community. This is viewed as supplementing the direction provided by the supervisor to each student. Although the professor remains the most important source of expertise, these additional transactions appear to be highly valued because they provide a "softer" analysis of the current state of student projects and allow successive approximations to knowledge related to the conduct of research; that is, the transactions that students have with each other help to reduce the cognitive gap between the novice researcher and the expert supervisor:

Having feedback from community members, in a meeting, you know, eight heads are better than one [laughter]. To have eight feedbacks when you're making a presentation rather than just the feedback from the supervisor is invaluable. Of course, other members of the community don't have the same expertise as the supervisor, but they bring a fresh perspective, a perspective that is new, a perspective that is both external to the thesis, but a perspective from the field. So, I find that the feedback is richer, more nourishing, more thought-provoking than if you were simply a student and your Master's supervisor [was] talking. (E7)

The exchanges between members go beyond feedback from student project presentations. Opportunities for collaborative work arise in the "thematic cells". Since these microstructures allow students to work together on a common project, they constitute privileged spaces to encourage transactions. In these research projects, the process is planned and executed collaboratively, and decisions are made collegially: 
I also appreciate the fact that people have dynamic projects. People have research projects and... they're going to... every time... there's such a thing we do. And they do things together. For example, for a project we decide together which experts to meet, which books to read, which theories. It's really done together, it's a co-construction... it's together. It's a co-construction, it's a common work, because we say we're going to meet this expert, this expert. We discuss about experts... ah! such and such an expert has such and such competence, we will see him. We make an appointment together, we decide together, we go together, we see him. We say ah! We look for books on such and such a thing and each one proposes. Ah! such and such a book could be of interest and so on. We say: each one makes a synthesis of his readings and... the project is finished. Everyone has learned something in this project. It's not just the supervisor alone. So, it's learning, it's a co-construction. (E6)

All of these exchanges bring an added value to the training of each student-researcher. It is therefore of utmost importance for them to be able to take advantage of these interactions in order to enhance their learning of the academic research process, in general, and to advance effectively in their thesis work, in particular. In order to achieve this, it is crucial that each member assume their role as a key player in the dynamics of the exchanges, and that they be able to compete in a synergistic manner. Student E2 explains this as follows:

There is this group effect, this volume effect, and I call it synergistic forces, and these synergistic forces cannot emerge in the one-to-one. I see it every time, every theme, every thing that's discussed there's the first one that brings, the second one that completes, [P1] brings then oops! someone who's going to bring another perspective then boom! people end up having something that at first seemed complex, difficult to model and verbalize, but after the exchange bang! you're able to say things in a very simple way with simple words and then you see that there's a capitalization process, it doesn't happen in one-to-one, it can happen in some cases, but not always, it seems that one-to-one is limited. (E2)

Another aspect of this capitalizing on exchanges is the improvement of oral communications. With the comments and questions of their peers, students can make mutual adjustments in their arguments or clarify what they say. Several participants point out the importance of exposing their reasoning in order to perceive, through feedback, the congruence between the intention and the act of communication, as well as between the message conveyed and the message understood by the audience. At a deeper level, the capitalizing on exchanges also manifests itself in the refinement of the objects of research through the dialogical dynamics between members:

So, I would retain that the major contribution of my peers is to allow me to see that it is a question of making what I said more precise and more convincing. Peers ask a lot of questions in all directions and therefore, it leads us to specify well, to announce well in advance where we want to go, at what limit we want to act and what we want to leave out. So, it allows us to specify what we are writing. (E9)

The written interactions taking place during the feedback of textual productions are also instances of capitalizing on exchanges. Through the comments and suggestions made by peers on the texts under development, students can improve their documents, while adjusting their writing to the style of the academic genre. This external view outside the research project, but within the field of study, seems to be of great value to students. For some students, such as E6, SCP at this level facilitates thesis writing: 
[...] for example, someone who is discouraged, perhaps his or her project is not strong enough. For example, someone who has submitted their thesis for preliminary evaluation. It can last because the thesis is not strong enough to pass. It can get stuck somewhere. But if we develop a level of scientific writing. If we reach a level of scientificity, we can correct each other. Maybe at the preliminary evaluation the thesis is good enough to pass quickly. When the thesis is not good enough, we can say there is such and such a thing to review, we must rewrite such and such a part, and that takes time. (E6)

By analyzing the participants' discourse, we can establish that the strengthening of SCP in the community translates into an increased level of dialogue between members, especially between students. In this way, the frequency and richness of interactions seem to be factors that would have a direct impact on the availability and connectedness perception.

\section{Socio-cognitive presence and development of autonomy}

The simultaneous presence of codes in the "SCP" category with codes in the "autonomy" category suggests that the existence of SCP in the community would promote, to a certain degree, the development of autonomy among student-researchers by capitalizing on the collaborative and mutual aid relationship with peers (Table 6).

Table6: Co-occurrences of the Codes from "SCP" and "Autonomy" Categories

\begin{tabular}{|l|cr|c|c|c|}
\hline SCP Autonomy & $\begin{array}{l}\text { Defining for } \\
\text { managing } \\
\text { project }\end{array}$ & $\begin{array}{l}\text { and } \\
\text { the }\end{array}$ & $\begin{array}{l}\text { Looking } \\
\text { solutions }\end{array}$ & Empowerment \\
\hline Confrontation & 21 & 33 & 21 & 13 \\
\hline Mutual adjustment & 46 & 68 & 35 & 24 \\
\hline Negotiation & 10 & 17 & 9 & 8 \\
\hline Deliberation & 28 & 39 & 23 & 18 \\
\hline Knowledge sharing & 22 & 37 & 16 & 16 \\
\hline Sharing difficulties & 18 & 30 & 11 & 8 \\
\hline Sharing experiences & 24 & 41 & 17 & 14 \\
\hline
\end{tabular}

Among the codes belonging to the "SCP" category, mutual adjustment interactions have the highest number of co-occurrences with codes in the "autonomy" category. This would indicate that, for all participants, great importance is given to interactions that promote awareness of their own thinking in relation to that of others, and reconsideration of their own representations and those of others, with the aim of transferring the "good moves" of peers to their own projects.

Reciprocally, the "looking for solutions" code falls under the "autonomy" category, which is the category with the highest number of simultaneous occurrences of codes under the "SCP" category. According to the participants' discourse, the most notable impact of transactions is on the development of the ability to "go into problem-solving mode". In other words, for student-researchers, the transactions that take place within the community enable them to equip themselves to overcome obstacles that they encounter in their own research projects.

Strengthening SCP through the encouragement of transactions would contribute to developing the student-researcher's ability to produce an effect on peers, to influence 
their projects, and to transform the community itself. This relationship between SCP and agentivity also appears to be reciprocal. Indeed, this ability of action and transformation would increase the intensity of transactions.

Peer-to-peer transactions contribute to the awareness that difficulties in conducting a student research project are not uncommon. These exchanges also contribute to developing an ability to find solutions to these difficulties:

\begin{abstract}
You know, seeing other students present their work, it helps me a lot, because it helps me to orient myself in relation to how I form the thread of my thesis, it helped me a lot to see examples, then I feel less alone in relation to my thesis when I see that others have the same difficulties, then they manage to get through it, they manage to overcome their obstacles, I feel less helpless about the obstacles that I encounter. I say to myself, well, there are others who have encountered it, it's doable, we can get over it. (E7)
\end{abstract}

Written interactions between students through feedback on textual productions can also contribute to refining a research project. Although these comments vary greatly in their relevance, they can also convey elements that add value to the project and contribute to its gradual evolution. Moreover, analyzing the relevance of these contributions is a valuable skill in academic research training that can be developed through interactions within the community:

People sometimes scan our writings, but it doesn't matter. They give you elements that sometimes you didn't even see. If you haven't seen it and it doesn't seem interesting, well, you get through it. But if you hadn't seen it and you say "oh, it's very interesting!" you've just added value to your work just by talking to others. Just by listening to others. So, you also have a gain on this qualitative dimension of the work and the other thing you find there as a professor is to know how to tell people that you have to learn to let go, because people will talk, they will make lots of comments and there will be comments that will have nothing to do with your work. So, you listen, you write down your notes and then you talk to your supervisor. (P2)

The heterogeneity of participant levels seems to be a determining factor in the dynamics of this community. Interactions take place between the following groups of students: students at the beginning of the Master's program, when they explore possibilities for research; students in the middle of the program, who are defining their projects or are in their empirical phase; and students at the end of the program, who are giving final form to their thesis. This co-presence is considered to be crucial for fostering a transfer of knowledge and skills:

All that is important in learning is to learn from the experience of others. Because when you are the first one, you think you are unhappy, whereas those who are advanced have also been like you. What the new student is going to produce as problem speech, what I have experienced, then the one who has a high level has also gone through that. In this exercise of sharing experiences, this is an important part of learning and it is very relevant because the one who has already passed the hurdle, he will be in a better position to explain how he did it and often the experiences are the same. We live almost the same situations. [...] (P4)

Finally, regarding the relationship between SCP and TD in this research training community, the results of this study show that there is a reciprocal modulation between these two elements. Thus, variations in the intensity and frequency of transactions 
cause fluctuations in availability and connectedness perception. Conversely, measuring TD would define the volume and quality of transactions.

\section{Discussion and conclusion}

Sharing experiences within the community influences both the individual and collective dimensions of supervision. The results of our study indicate that the relationship between SCP and TD in this community is characterized by reciprocity. On the one hand, transactions between community members affect the perception of availability and connection. The strength of interactions is a function of the frequency, relevance and richness of the knowledge and experiences they convey. These transactions shape supervision. On the other hand, the level of community structure, dialogue dynamics and degree of student autonomy are determinants of the frequency and depth of transactions. The organization of supervision (structure) then determines interaction dynamics (SCP). Figure 6 illustrates reciprocity between SCP and structure.

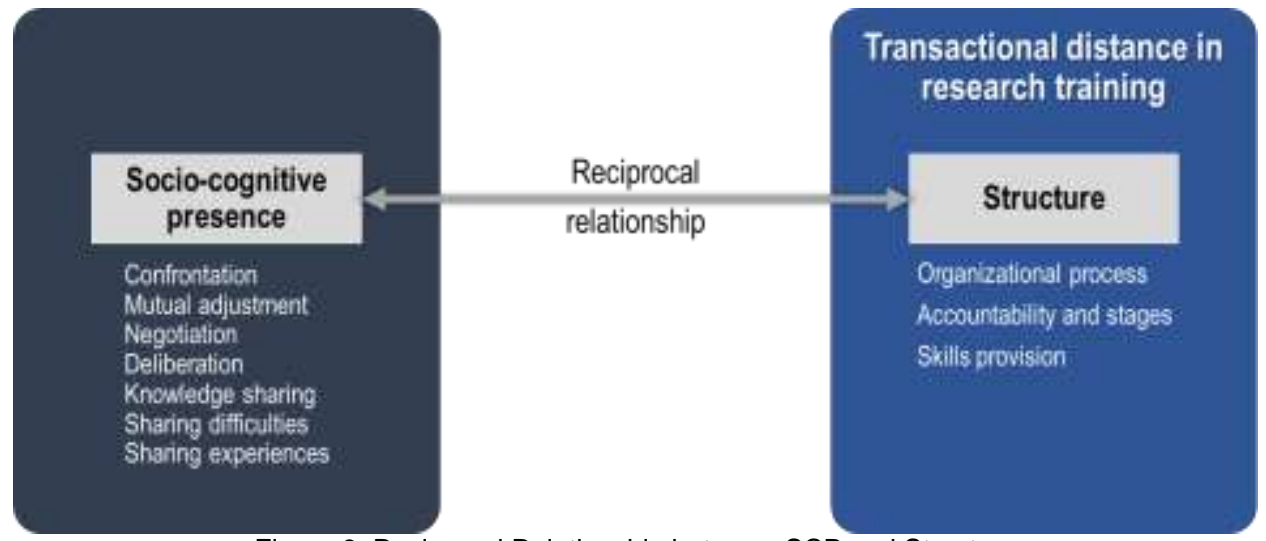

Figure 6: Reciprocal Relationship between SCP and Structure

Source: Author, 2020

Regarding the relationship between SCP and dialogue, the results of the analysis prove that the value of dialogue as a modulating element of TD is largely defined by the opportunity to exchange or share knowledge and experiences (successes, barriers, approaches). Participants see the community as a space for discussion, collegial reflection and negotiation. In this sense, technologies play a key role if they are used as transformative elements of supervision, and not as a means of replicating the one-toone model. Both synchronous devices (e.g., videoconferencing systems) and asynchronous devices (e.g., Learning Management System (LMS), digital portfolios, content curation platforms, discussion forums, etc.) offer interesting opportunities to extend research training beyond two-way interactions with the supervisor. This supports the findings of Donnelly and Fitzmaurice (2013):

Previously what had been regarded by academics as a private space has moved to welcome the potential of collaboration and [...] has shifted to being more visible, more open for discussion, reflection and negotiation. With the dramatic increase of learning technologies available in higher education today, what has been described as a lonely endeavour by students and supervisors alike, need not be so. [...] Supervision should be conceptualised to encompass a broad view of postgraduate education that includes more than the one-to-one interaction of student and supervisor. [...] There is a need to go beyond individual supervisory interaction and restructure practice to ensure that responsibility for quality is shared and coordinated (Donnelly and Fitzmaurice 2013, 2-3). 
Theoretically, we find that SCP (Jézégou 2012) can be equated with dialogue as a component of TD (Moore 1993). This identity relationship between SCP and dialogue (Figure 7) confirms what was observed by Steele, Shackel, and Bell (2012): critical dialogue during community activities encourages the expression of divergent opinions, confrontation and mutual adjustment. "Often, sense making was performed through continuous discourses that co-constructed and negotiated meaning on a project idea" (Steele, Shackel, and Bell 2012, 4). Learning and knowledge emerge from a diversity of opinions, and the modelling of critical thinking by faculty facilitates recognition of this diversity.

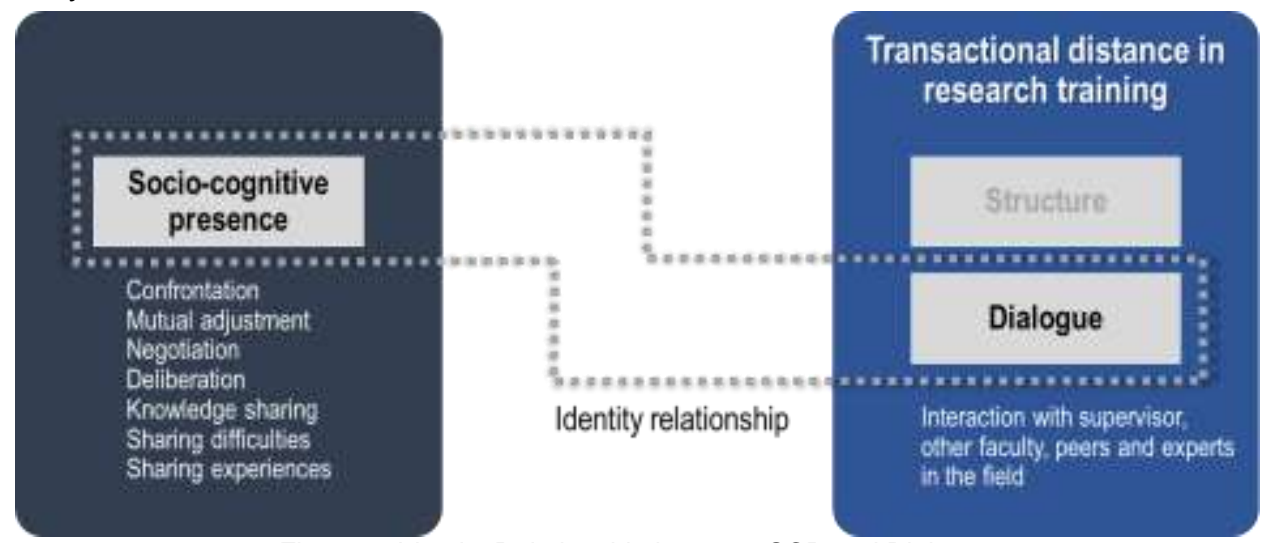

Figure 7: Identity Relationship between SCP and Dialogue

Source: Author, 2020

Concerning the relationship between SCP and autonomy, we found that involvement in the dynamics of transactions between community members contributes to the following: first, to the development of the students' ability to undertake the actions necessary to advance their research projects; secondly, to their ability to assist with peers' projects; and, thirdly, to the evolution of the community. The relationship between the frequency of transactions and the development of agentivity is also reciprocal. Thus, the development of the above-mentioned abilities adds value to interactions.

In this community, student autonomy is also reinforced by the possibility of participating in the dynamics of co-evaluation of written productions related to dissertations and the use of common criteria to control the quality of their texts. Pyhältö et al. (2012) had already mentioned this potential of a collective supervision system: "Through the use of blended group supervision (BGS), where students can utilize group feedback to develop independence and increased ability to self-assess through virtual peer learning, these supervision issues [unavailability, disconnection] can be tackled" (Pyhältö et al. 2012, 231).

The results allowed us to identify an important impact of peer transactions on management of student projects; these interactions highlight the fact that difficulties in conducting a dissertation are more common than one might think. Thus, these exchanges contribute to developing the ability to find solutions. If, on the one hand, transactions that take place within the community seem to contribute to the development of students' autonomy with respect to their research projects, then the ability to conduct research, to find solutions to difficulties encountered and to influence the community would, in turn, contribute to an increased SCP. Figure 8 illustrates this reciprocity between SCP and autonomy. 


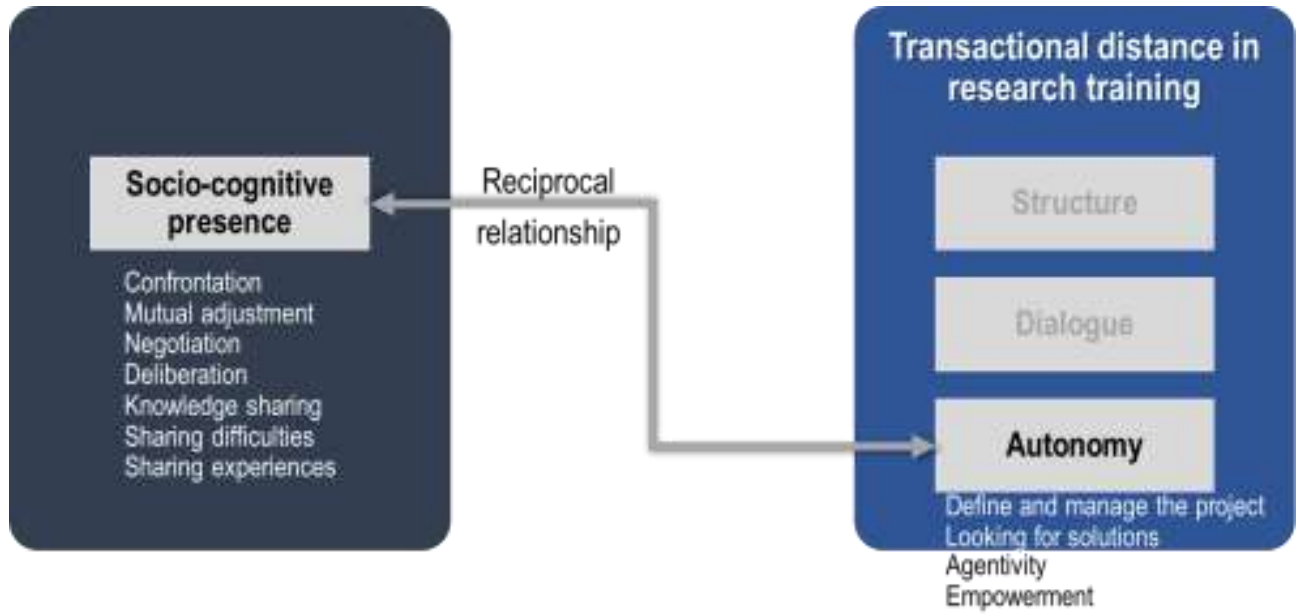

Figure 8: Reciprocal Relationship between SCP and Autonomy

Source: Author, 2020

In our view, the fact that students can have meaningful and relevant interactions with peers in their field is an interesting opportunity that complements individual supervision. In this regard, we agree with Darder and Pérez (2015):

The student needs to mix with other peers who find themselves in the same situation because this favors information exchange as well as communication, and it also causes loneliness to disappear, it enriches work and provides motivation. Virtual communities make it easier to achieve this, which represents an important solution to this need in our opinion. Similarly, it is our conviction that research and the student-tutor relationship may become richer if consideration of the supervisor as an isolated individual is left aside and virtual communities of research project tutors are created within institutions that allow them both not only to share experiences and information but also to interact and support one another (Darder and Pérez 2015, 130).

The results of this study are indicative of the reciprocity that characterizes the relationship between SCP and TD in this community. On the one hand, the volume and richness of transactions modulate the perception of availability and connection. On the other hand, TD defines the intensity and frequency of exchanges. 


\section{REFERENCES}

Bardin, Laurence. 2013. L'analyse de contenu [Content Analysis], 2nd edition. Paris: Presses Universitaires de France.

Belleville, Geneviève. (2014). Assieds-toi et écris ta thèse! [Sit Down and Write Your Thesis!], 5th edition. Québec: Presses de l'Université Laval.

Boud, David and Alison Lee, A. 2005. "Peer Learning as Pedagogic Discourse for Research Education". Studies in Higher Education, 30 (5), 501-516. https://doi.org/10.1080/03075070500249138

Choy, Sarojni, Brian L. Delahaye, and Beth Saggers. 2014. "Developing Learning Cohorts for Postgraduate Research Degrees". The Australian Educational Researcher, 42 (1), 19-34. https://doi.org/10.1007/s13384-014-0147-y

Conrad, Linda. 2006. "Countering Isolation: Joining the Research Community" In Doctorates Downunder: Keys to Successful Doctoral Study in Australia and New Zealand, edited by Denholm, Carey and Terry Evans, 34-40. Camberwell: ACER Press.

Cotterall, Sara Maureen. 2011. "Stories Within Stories: A Narrative Study of Six International Phd Researchers' Experiences of Doctoral Learning in Australia". PhD diss., Macquarie University, Sydney.

Crossouard, Barbara. 2008. "Developing Alternative Models of Doctoral Supervision with Online Formative Assessment". Studies in Continuing Education, 30 (1), 51-67. https://doi.org/10.1080/01580370701841549

Darder, Antonia, and Adolfina Pérez. 2015. "Online Tutoring Procedure for Research Project Supervision: Management, Organization and Key Elements". Journal of New Approaches in Educational Research (NAER Journal), 4 (2), 123-132. https://doi.org/10.7821/naer.2015.4.110

Dewey, Jhon, and Arthur Fisher Bentley. 1949. "Knowing and the Known". In John Dewey: The Later Works (Vol. 16) edited by Jo Ann Boydston, 1925-1953. Carbondale: Southern Illinois University Press.

Donnelly, Roisin, and Marian Fitzmaurice. 2013. "Development of a Model for Blended Postgraduate Research Supervision in Irish Higher Education". In Emerging Issues in Higher Education III, From Capacity Building to Sustainability, edited by O'Farrell, Ciara and Alison Farrell, 193-209. Belfast: Educational Developers in Ireland Network (EDIN).

Evans, Terry, Christopher Hickey, and Heather Davis. 2004. "Research Issues Arising from Doctoral Education at a Distance". Research in Distance Education, 6, 120-131.

Evans, Terry. 2002. "Part-time Research Students: Are They Producing Knowledge Where It Counts?" Higher Education Research \& Development, 21 (2), 155-165. https://doi.org/10.1080/07294360220144079

Ewing, Helen, Mathieson, Kathleen, Alexander, Jeffrey, and Joan Leafman. 2012. "Enhancing the Acquisition of Research Skills in Online Doctoral Programs: The Ewing Model()". MERLOT Journal of Online Learning and Teaching, 8 (1), 3444.

Flores-Scott, Emma, and Maresi Nerad. (2012). "Peers in Doctoral Education: Unrecognized Learning Partners". New Directions for Higher Education, 157 (Spring), 73-83. https://doi.org/10.1002/he.20007 
Ford, Lance, Gracie Branch, and George Moore. 2008. "Formation of a Virtual Professional Learning Community in a Combined Local and Distance Doctoral Cohort". AACE Journal, 16 (2), 161-185.

Gatfield, Terry. 2005. "An Investigation into PhD Supervisory Management Styles: Development of a Dynamic Conceptual Model and Its Managerial Implications". Journal of Higher Education Policy and Management, 27 (3), 311-325. https://doi.org/10.1080/13600800500283585

Godskesen, Mirjam, and Sofie Kobayashi. 2016. "Coaching Doctoral Students-a Means to Enhance Progress and Support Self-organisation in Doctoral Education". Studies in Continuing Education, 38 (2), 145-161. https://doi.org/10.1080/0158037X.2015.1055464

Green, Rosemary. 2006. "Fostering a Community of Doctoral Learners". Journal of Library Administration, $45 \quad$ (1-2), 169-183. https://doi.org/10.1300/J111v45n01_09

Grossman, Elly, and Nigel Crowther. 2015. "Co-supervision in Postgraduate Training: Ensuring the Right Hand Knows What the Left Hand Is Doing". South African Journal of Science, 111 (11-12), 1-8.

Habib, Adam, and Seán Morrow. 2007. "Research, Research Productivity and the State in South Africa". Journal of Higher Education in Africa, 5 (1), 113-130. https://doi.org/10.1353/trn.2007.0006

Hernández-Sampieri, Roberto, and Christian Paulina Mendoza. 2018. Metodología de la investigación. Las rutas cuantitativa, cualitativa y mixta [Research Methodology. The Quantitative, Qualitative and Mixed Approaches]. Ciudad de México, México: Editorial Mc Graw Hill Education.

Ismail, Affero, Norhasni Zainal Abiddin, and Aminuddin Hassan. 2011. "Improving the Development of Postgraduates' Research and Supervision”. International Education Studies, 4 (1), 78-89. https://doi.org/10.5539/ies.v4n1p78

Jézégou, Annie. 2010. "Créer de la présence à distance en e-learning" [Creating Remote Presence in E-Learning.]. Distances et savoirs [Distances and Knowledge], 8 (2), 257-274.

Jézégou, Annie. 2012. "La présence en e-learning: modèle théorique et perspectives pour la recherche" [Presence in E-learning: Theoretical Model and Perspectives for Research]. International Journal of E-Learning \& Distance Education, 26 (1).

Jézégou, Annie. 2013. "La présence en e-learning: une dimension socio-éducative pour favoriser l'autodirection des apprenants" [Presence in E-learning: a Socioeducational Dimension to Encourage Learners' Self-direction]. In Renforcer l'autoformation: aspects sociaux et dimensions pédagogiques [Reinforcing Selftraining: Social Aspects and Pedagogical Dimensions], edited by Cyrot, Pascal, Jeunesse, Christophe, and Denis Christol, 145-158. Lyon: Chronique sociale.

Jézégou, Annie. 2014. "Le modèle de la présence en e-learning. Une modélisation théorique au service de la pratique, notamment en contexte universitaire" [The E-learning Presence Model. Theoretical Modeling at the Service of Practice, Particularly in a University Context]. In La pédagogie universitaire à l'heure du numérique [University Pedagogy in the Digital Age], edited by Lameul, Geneviève and Catherine Loisy, 111-120. Bruxelles: De Boeck Université.

Jézégou, Annie. 2019. "La distance, la proximité et la présence en e-formation" [Distance, Proximity and Presence in E-learning]. In Traité de la e-formation des adultes [Treatise on Adult E-learning], edited by Jézégou , Annie, 143-163. Bruxelles: De Boeck Université. 
Johnston, Sue. 1995. "Building a Sense of Community in a Research Master's Course". Studies in Higher Education, 20 (3), 279-291. https://doi.org/10.1080/03075079512331381555

Lee, Joyce, Carter-Wells, JoAnn, Glaeser, Barbara, Ivers, Karen, and Chris Street. 2006. "Facilitating the Development of a Learning Community in an Online Graduate Program". Quarterly Review of Distance Education, 7 (1), 13-33.

Lee, Anne. 2008. "How Are Doctoral Students Supervised? Concepts of Doctoral Research Supervision". Studies in Higher Education, 33 (3), 267-281. https://doi.org/10.1080/03075070802049202

Lee, Anne. 2019. Successful Research Supervision: Advising Students Doing Research. 2nd edition. London: Routledge. https://doi.org/10.4324/9781351234986

Lovitts, Barbara. 2005. "Being a Good Course-taker Is Not Enough: a Theoretical Perspective on the Transition to Independent Research". Studies in Higher Education, 30 (2), 137-154. https://doi.org/10.1080/03075070500043093

Mainhard, Tim, van der Rijst, Roeland, van Tartwijk, Jan, and Theo Wubbels. 2009. "A Model for the Supervisor-doctoral Student Relationship". Higher Education, 58 (3), 359-373. https://doi.org/10.1007/s10734-009-9199-8

Maltais, Martin, and André-Jacques Deschênes. 2013. "L'encadrement par les pairs à distance à l'université: vers un service institutionnel" [Distance Peer Coaching at the University: Towards an Institutional Service]. In Le tutorat de pairs dans l'enseignement supérieur. Enjeux institutionnels, technopédagogiques, psychosociaux et communicationnels [Peer Tutoring in Higher Education. Institutional, Technopedagogical, Psychosocial and Communication Issues], edited by Cathia Papi, 159-188. Paris: L'Harmattan.

McAlpine, Lynn, and Cheryl Amundsen. 2015. "Early Career Researcher Challenges: Substantive and Methods-based Insights". Studies In Continuing Education, 37, 1-17. https://doi.org/10.1080/0158037X.2014.967344

Mills, John. 2002. "Intellectual Isolation, Geographical Isolation and Information Overload of Academics at a Rural University: an Information-seeking Perspective". Rural Society, 12 (3), 263-272. https://doi.org/10.5172/rsj.12.3.263

Mitchell, Theresa, and Jude Carroll. 2008. "Academic and Research Misconduct in the Phd: Issues for Students and Supervisors". Nurse Education Today, 28 (2), 218226. https://doi.org/10.1016/j.nedt.2007.04.003

Moore, Michael Graham. 1993. "Theory of Transactional Distance". In Theoretical Principles of Distance Education, edited by Desmond Keegan, 20-35. New York: Routledge.

Munich, Kim. 2014. "Social Support for Online Learning: Perspectives of Nursing Students". International Journal of E-Learning \& Distance Education, 29 (2), 112.

Nordentoft, Helle Merete, Rie Thomsen, and Gitte Wichmann-Hansen. 2013. "Collective Academic Supervision: a Model for Participation and Learning in Higher Education". Higher Education, 65 (5), 581-593. https://doi.org/10.1007/s10734012-9564-x

Olson, Kate, and Christopher M. Clark. 2009. "A Signature Pedagogy in Doctoral Education: The Leader-Scholar Community". Educational Researcher, 38 (3), 216-221. https://doi.org/10.3102/0013189X09334207

Overall, Nickola, Deane, Kelsey, and Elizabeth R. Peterson. 2011. "Promoting Doctoral Students' Research Self-efficacy: Combining Academic Guidance with 
Autonomy Support”. Higher Education Research \& Development, 30 (6), 791 805. https://doi.org/10.1080/07294360.2010.535508

Paliktzoglou, Vasileios, Rogers, Clint, and Jarkko Suhonen. 2010. "Design Challenges of Developing an Online Phd Supervision Community". In Proceedings of the 5th Annual South-East European Doctoral Student Conference, edited by Psychogios, Alexandros, Proedrou, Filippos, Kalyva, Efrosyni, and George Eleftherakis, 41-411. Thessaloniki, Greece : South-East European Research Centre.

Papi, Cathia. (2013). "Richesse du tutorat de pairs dans une formation hybride. Analyse de l'activité des moniteurs C2i" [Richness of Peer Tutoring in a Hybrid Training. Analysis of the Activity of $\mathrm{C} 2 \mathrm{i}$ Instructors]. In Le tutorat de pairs dans l'enseignement supérieur. Enjeux institutionnels, technopédagogiques, psychosociaux et communicationnels [Peer Tutoring in Higher Education. Institutional, Technopedagogical, Psychosocial and Communication Issues], edited by Cathia Papi, 141-158. Paris: L'Harmattan.

Parker, Rachel. 2009. "A Learning Community Approach to Doctoral Education in the Social Sciences". Teaching in Higher Education, 14 (1), 43-54. https://doi.org/10.1080/13562510802602533

Pyhältö, Kirsi, Nummenmaa, Anna Raija, Soini, Tiina, Stubb, Jenni, and Kirsti Lonka. 2012. "Research on Scholarly Communities and the Development of Scholarly Identity in Finnish Doctoral Education". In Higher Education Research in Finland: Emerging Structures and Contemporary Issues, edited by Ahola, Sakari and David Hoffman, 337-357). Jyväskylä, Finland: Jyväskylä University Press.

Samara, Akylina. 2006. "Group Supervision in Graduate Education: a Process of Supervision Skill Development and Text Improvement". Higher Education $\begin{array}{llll}\text { Research \& Development, } 25 & \text { (2), } & 115-129 .\end{array}$ https://doi.org/10.1080/07294360600610362

Shin, Namin. 2002. "Beyond Interaction: The Relational Construct of 'transactional Presence"'. Open Learning: The Journal of Open, Distance and e-Learning, 17 (2), 121-137. https://doi.org/10.1080/02680510220146887

Silinda, Fortunate T., and Michael Brubacher. 2016. "Distance Learning Postgraduate Student Stress while Writing a Dissertation or Thesis". International Journal of E-Learning \& Distance Education, 31 (1), 1-14.

Steele, Linda Roslyn, Shackel, Rita, and Felicity Bell. 2012. "The Importance of the Local in a Global Age: Analysis of Networking Strategies in Postgraduate Law Research Learning". Journal of the Australasian Law Teachers Association, 5 (1-2), 1-13.

van der Meer, Jacques, Lucy Spowart, and Simon Hart. 2013. "We Need Support Too: Providing Postgraduate Peer Support!". In The Student Engagement Handbook: Practice in Higher Education, edited by Dunne, Elisabeth and Derfel Owen, 313-330. UK: Emerald Group Publishing Limited.

Wagener, Bastien, Christophe Boujon, and Benoît Fromage. 2010. "Métacognitions, émotions et motivations" [Metacognitions, Emotions and Motivations]. Psychologie internationale, pratiques et recherche [International Psychology, Practice and Research], 1, 89-109.

Wegener, Charlotte, Ninna Meier, and Karen Ingerslev. 2014. "Borrowing Brainpower Sharing Insecurities. Lessons Learned from a Doctoral Peer Writing Group". 
Studies in Higher Education, $41 \quad$ (6), 1092-1105. https://doi.org/10.1080/03075079.2014.966671

Wichmann-Hansen, Gitte, Thomsen, Rie, and Helle Merete Nordentoft. 2014. "Challenges in Collective Academic Supervision: Supervisors' Experiences from a Master Programme in Guidance and Counselling". Higher Education, 70 (1), 19-33. https://doi.org/10.1007/s10734-014-9821-2

Willems, Julie, Farley, Helen, Ellis, Allan, McCormick, Debbie, and Dan Walker, 2013. "Supervising Higher Degree Research (HDR) Candidates at a Distance: What Do Emerging Virtual World Technologies Have to Offer?". In Outlooks and Opportunities in Blended and Distance Learning, edited by Tynan, Belinda, Willems, Julie, and Rosalind James, 369-382. PA: IGI Global. https://doi.org/10.4018/978-1-4666-4205-8

Wisker, Gina. 2007. "Supervising Postgraduates: Internationally, and at a Distance". In Connections: Sharing the Learning Space. Articles from the Learning and Teaching Conference 2007, edited by Barlow, Joyce, Louw, Gail, and Mark Price, 23-28. Brighton: University of Brighton Press.

Wright, Laurence. 2016. "Brave Old World: Can Today's University Truly Be 'home' to Tomorrow's Minds?". South African Journal of Science, 112 (1-2), 1-2. 